\title{
HUBUNGAN FAKTOR SOSIAL EKONOMI KELUARGA, POLA KONSUMSI PANGAN DAN RIWAYAT PENYAKIT INFEKSI PADA IBU HAMIL DI KECAMATAN OEBOBO KOTA KUPANG
}

\author{
RELATIONSHIP OF FAMILY SOCIAL ECONOMIC FACTORS, FOOD \\ CONSUMPTION PATTERNS AND HISTORY OF INFECTION DISEASES \\ IN PREGNANT MOTHERS IN OEBOBO DISTRICT, KUPANG CITY
}

\author{
Astuti Anastasia Tri, Intje Picauly, Mindo Sinaga
}

Ilmu Kesehatan Masyarakat, Program Pascasarjana, Universitas Nusa Cendana - Kupang

\begin{abstract}
ABSTRAK
Kekurangan energi kronis (KEK) dalam kehamilan telah banyak diketahui memiliki dampak negatif pada ibu dan janin yang dikandungnya. Dampak negatif yang paling menonjol adalah meningkatnya risiko kematian ibu dan bayi saat melahirkan. KEK pada wanita hamil dapat disebabkan oleh ketidakseimbangan asupan gizi dan penyakit menular. Tujuan dari penelitian ini adalah untuk mengetahui dan menganalisis korelasi antara faktor sosial ekonomi keluarga (usia, pendidikan, pekerjaan, pendapatan, jumlah anggota keluarga, dukungan keluarga), pola konsumsi makanan (jenis makanan, jumlah makanan, frekuensi makan, larangan makanan) dan riwayat penyakit menular peristiwa KEK pada wanita hamil. Jenis penelitian yang digunakan adalah penelitian analitik observasional dengan desain cross sectional. Pengambilan sampel secara total sampling dengan ukuran sampel 72 responden. Instrumen yang digunakan adalah kuesioner dan format penarikan makanan 24 jam. Analisis data dilakukan dalam tiga tahap: analisis univariat, analisis bivariat dengan metode analisis chi square, analisis multivariat dengan metode analisis regresi logistik berganda. Hasil penelitian berdasarkan analisis bivariat menunjukkan bahwa variabel yang berhubungan dengan kejadian KEK pada ibu hamil adalah pendidikan dengan $\mathrm{p}=0,001(\mathrm{p}<0,05)$, pekerjaan dengan nilai $\mathrm{p}$ $=0,000(\mathrm{p}<0,05)$, pendapatan dengan nilai $\mathrm{p}=0,000(\mathrm{P}<0,05), \mathrm{p}=0,000(\mathrm{p}<0,05), \mathrm{p}=0,000(\mathrm{p}$ $<0,05)$, konsumsi makanan dengan $\mathrm{p}=0,000(\mathrm{p}<0,05), 05)$, dan frekuensi makan dengan nilai $\mathrm{p}=$ $0,008(\mathrm{p}<0,05)$. Analisis multivariat menunjukkan bahwa variabel yang terkait dengan kejadian CED pada wanita hamil adalah variabel pekerjaan dengan nilai $\mathrm{p}=0,026$. Ada korelasi yang signifikan antara faktor sosial ekonomi keluarga (pendidikan, pekerjaan, pendapatan, dukungan keluarga) dan pola konsumsi makanan (jenis makanan, jumlah konsumsi makanan dan frekuensi makan) dengan kejadian KEK pada wanita hamil. Secara simultan maka ada satu variabel yang memiliki hubungan signifikan dengan kejadian KEK pada ibu hamil yaitu bekerja.
\end{abstract}

Kata Kunci : Kekurangan Energi Kronis, Ibu Hamil, Sosial Ekonomi

\begin{abstract}
Chronic energy deficiency (CED) in pregnancy has been widely known to have a negative impact on the mother and the fetus it contains. The most prominent negative impact is the increased risk of maternal and infant deaths during childbirth. CED in pregnant women can be caused by an imbalance of nutritional intake and infectious diseases. The aim of this research is to know and analyze the correlation between family socioeconomic factors (age, education, occupation, income, number of family members, family support), food consumption pattern (food type, food quantity, feeding frequency, food prohibition) and history of infectious diseases CED events in pregnant women.The type of research used is observational analytic research with cross sectional design. Sampling in total sampling with a sample size of 72 respondents. The instrument used is questionnaire and 24 hour food recall format. Data analysis was done in three stages: univariate analysis, bivariate analysis with chi square analysis method, multivariate analysis with multiple logistic regression analysis method. The results of the study based on bivariate analysis showed that the variables
\end{abstract}


associated with CED occurrence in pregnant women were education with $p=0,001(p<0,05)$, job with $\mathrm{p}$ value $=0,000(\mathrm{p}<0,05)$, income with $\mathrm{p}$ value $=0,000(\mathrm{P}<0,05), \mathrm{p}=0,000(\mathrm{p}<0,05), \mathrm{p}=0,000(\mathrm{p}$ $<0,05)$, food consumption with $\mathrm{p}=0,000(\mathrm{p}<0,05), 05)$, and feeding frequency with value $\mathrm{p}=0,008$ $(\mathrm{p}<0,05)$. Multivariate analysis showed that variables associated with CED occurrence in pregnant women were job variable with $\mathrm{p}$ value $=0,026$. There is a significant correlation between family socioeconomic factors (education, occupation, income, family support) and food consumption pattern (type of food, amount of food consumption and frequency of eating) with CED occurrence in pregnant women. Simultaneously then there is one variable that has a significant relationship with CED occurrence in pregnant women that is work.

Key Words : Chronic Energy Deficiency, Pregnant Women, Socio-Economic

\section{PENDAHULUAN}

Departemen Kesehatan RI tahun 2002 menyatakan bahwa kekurangan energi kronis (KEK) pada kehamilan telah banyak diketahui memberikan dampak negatif pada ibu serta janin yang dikandungnya. Hal ini disebabkan karena ketidakseimbangan asupan gizi dan penyakit infeksi. Pemenuhan asupan gizi pada ibu hamil tentunya dipengaruhi oleh banyak faktor seperti faktor sosial ekonomi dan pengetahuan ibu hamil tentang kecukupan zat gizi selama kehamilan. Dari hasil penelitian Susilo (2000) diperoleh hasil bahwa KEK pada ibu hamil di Bantul sekitar 28,69\% disebabkan oleh pola makan yang tidak baik, 17,2\% memiliki frekuensi makan kurang dari 3 kali per hari dan 55,7\% memiliki porsi makan selama hamil lebih sebelum hamil. Keadaan ini apabila berlangsung lama akan memudahkan ibu hamil sebagai kelompok rawan untuk lebih mudah terserang penyakit infeksi yang kemudian akan mempercepat malnutrisi.

Riset Kesehatan Dasar (Riskesdas) 2013 menunjukkan bahwa terjadi peningkatan proporsi ibu hamil usia 15-19 tahun dengan KEK dari 31,3\% pada tahun 2010 meningkat menjadi 38,5\% pada tahun 2013. Disamping itu proporsi ibu hamil usia 15-49 tahun dengan LILA $<23,5 \mathrm{~cm}$ atau beresiko KEK di Indonesia sebesar 24,2\% dimana Provinsi NTT menempati urutan kasus tertinggi yakni sebesar $45,5 \%$.

Laporan Dinas Kesehatan Kota Kupang, menunjukkan prevalensi KEK di Kota Kupang pada tahun 2012 sebanyak 16,84\%, kemudian prevalensinya menurun menjadi 13.98\% di tahun 2013 hingga 13\% di tahun 2014. Meskipun prevalensinya menurun, namun kejadian KEK masih dianggap sebagai masalah kesehatan masyarakat khususnya di Kota Kupang karena prevalensinya melebihi standar minimal prevalensi KEK secara nasional yakni $\geq 10 \%$ (Depkes RI, 2009). Berdasarkan survey awal yang dilakukan di 10 Puskesmas yang tersebar di 6 Kecamatan di Kota Kupang, Kecamatan Oebobo merupakan salah satu Kecamatan yang memiliki kejadian ibu hamil KEK yang cukup tinggi yakni sebanyak $28,2 \%$. Dengan mempertimbangkan hal tersebut, maka peneliti menganggap penting untuk mengetahui hubungan faktor sosial ekonomi keluarga, pola konsumsi pangan, dan riwayat penyakit infeksi dengan kejadian KEK pada ibu hamil di Kecamatan Oebobo Kota Kupang.

\section{METODOLOGI PENELITIAN}


Jenis penelitian ini adalah observasional analitik dengan rancangan penelitian cross sectional. Populasi dalam penelitian ini adalah semua ibu hamil trimester II dan III yang ada diwilayah kerja Puskesmas Oebobo dan Puskesmas Oepoi. Teknik pengambilan sampel dilakukan dengan menggunakan teknik total sampling, dimana jumlah sampel sama dengan jumlah populasi yang berjumlah 72 responden. Teknik pengambilan data dilakukan dengan wawancara langsung terhadap responden dengan menggunakan kuesioner dan lembar food recall 24 jam. Analisa data dilakukan dalam tiga tahap yaitu analisis univariat, analisis bivariat dengan metode analisis chi square, analisis multivariat dengan metode analisis regresi logistik berganda.

\section{HASIL DAN PEMBAHASAN}

\section{A. Karakteristik Responden Penelitian}

Hasil analisis univariat yang menjelaskan distribusi frekuensi berdasarkan karakteristik responden yaitu status keluarga, paritas, dan umur kehamilan. Secara umum sebagian besar responden ibu hamil yang berdomisili di Kecamatan Oebobo berdasarkan variabel status keluarga diketahui bahwa 59 orang $(81,9 \%)$ responden telah berstatus menikah, namun terdapat 13 orang $(18,1 \%)$ responden yang belum menikah dimana sebagian besar dari mereka memiliki usia $<20$ tahun dan masih berstatus sebagai pelajar. Berdasarkan variabel paritas diketahui bahwa 33 orang $(45,8 \%)$ responden mempunyai status nulipara, dimana berdasarkan variabel umur kehamilan diketahui bahwa 45 orang $(62,5 \%)$ responden memiliki usia kehamilan trimester II (16-24 minggu).

\section{B. Faktor Sosial Ekonomi Responden Penelitian}

Faktor sosial ekonomi keluarga ibu hamil berdasarkan variabel umur ibu diketahui bahwa 43 orang $(59,7 \%)$ responden memiliki umur 20 - 35 tahun, dengan tingkat pendidikan tertinggi $(63,9 \%)$ ialah tingkat pendidikan sedang (SMA). Jika dilihat dari variabel pekerjaan diketahui bahwa mayoritas pekerjaan yang dilakukan oleh kepala keluarga merupakan pekerjaan yang bersifat tidak tetap yaitu sebanyak 43 orang $(59,7 \%)$, dengan pendapatan $(58,3 \%)$ responden memiliki pendapatan kecil (< Rp. 1.500.000). Berdasarkan variabel jumlah anggota keluarga diketahui bahwa 63,9\% responden memiliki jumlah anggota keluarga $>4$ orang dengan variabel dukungan keluarga diketahui bahwa $47,2 \%$ responden cukup mendapat dukungan keluarga selama periode kehamilan baik itu dukungan sosial yang bisa diwujudkan dalam bentuk kesiapan finansial, dukungan informasi, serta dukungan psikologis seperti menemani responden saat pergi memeriksakan diri.

\section{Pola Konsumsi Pangan Responden Penelitian}

Hasil analisis univariat yang menjelaskan distribusi frekuensi berdasarkan variabel independen yaitu pola konsumsi pangan (jenis pangan, jumlah pangan, frekuensi makan, dan pantangan makanan) diketahui bahwa $43,1 \%$ responden mengkonsumsi makanan dengan jenis pangan yang kurang beragam dimana hanya18,1\% responden mengkonsumsi energi dan protein dalam jumlah yang baik dan sebanyak 45,8\% responden mengkonsumsi energi dan protein dalam jumlah yang kurang 
meskipun $87,5 \%$ responden memiliki frekuensi makan $\geq 3$ kali sehari dan 95,8\% responden tidak memiliki pantangan terhadap semua jenis makanan.

\section{Riwayat Penyakit Infeksi Responden Penelitian}

Berdasarkan variabel riwayat penyakit infeksi diketahui bahwa 5,6\% responden diantaranya pernah memiliki riwayat penyakit infeksi seperti tipes dan diare sedangkan $94,4 \%$ responden tidak memiliki riwayat penyakit infeksi.

\section{E. Hubungan Faktor Sosial Ekonomi Keluarga dengan Kejadian Kurang Energi Kronis Pada ibu Hamil}

Tabel 1. Hubungan Faktor Sosial Ekonomi Keluarga dengan Kejadian KEK Pada Ibu Hamil di Kecamatan Oebobo Kota Kupang Tahun 2016

\begin{tabular}{|c|c|c|c|c|c|c|c|}
\hline \multirow[b]{2}{*}{$\begin{array}{c}\text { Faktor Sosial Ekonomi } \\
\text { Keluarga }\end{array}$} & \multicolumn{7}{|c|}{ Kejadian Kurang Energi Kronis Pada Ibu Hamil } \\
\hline & KEK & $\%$ & $\begin{array}{l}\text { Tidak } \\
\text { KEK }\end{array}$ & $\%$ & Total & $\%$ & $p$ value \\
\hline \multicolumn{8}{|l|}{ Umur Ibu } \\
\hline Resiko & 15 & 20,8 & 14 & 19,5 & 29 & 40,3 & \multirow{2}{*}{0,256} \\
\hline Tidak beresiko & 28 & 38,9 & 15 & 20,8 & 43 & 59,7 & \\
\hline \multicolumn{8}{|l|}{ Pendidikan } \\
\hline Rendah (SD,SMP) & 16 & 22,2 & 2 & 2,8 & 18 & 25,0 & \multirow{3}{*}{0,001} \\
\hline Sedang (SMA) & 26 & 36,1 & 20 & 27,8 & 46 & 63,9 & \\
\hline Tinggi $(\mathrm{PT})$ & 1 & 1,4 & 7 & 9,7 & 8 & 11,1 & \\
\hline \multicolumn{8}{|l|}{ Pekerjaan } \\
\hline Pekerjaan & 38 & 52,8 & 5 & 6,9 & 43 & 59,7 & \multirow{3}{*}{0,000} \\
\hline Tidak Tetap & & & & & & & \\
\hline Pekerjaan Tetap & 5 & 6,9 & 24 & 33,4 & 29 & 40,3 & \\
\hline \multicolumn{8}{|l|}{ Pendapatan } \\
\hline $\begin{array}{l}\text { Kecil } \\
(<\text { Rp. } 1.500 .000)\end{array}$ & 39 & 54,2 & 3 & 4,2 & 42 & 58,4 & \multirow{2}{*}{0,000} \\
\hline $\begin{array}{l}\text { Besar } \\
(\geq \text { Rp. 1.500.000) }\end{array}$ & 4 & 5,5 & 26 & 36,1 & 30 & 41,6 & \\
\hline \multicolumn{8}{|l|}{$\begin{array}{l}\text { Jumlah } \\
\text { Anggota Keluarga }\end{array}$} \\
\hline$>4$ orang & 27 & 37,5 & 19 & 26,4 & 46 & 63,9 & \multirow{2}{*}{0,813} \\
\hline$\leq 4$ orang & 16 & 22,2 & 10 & 13,9 & 26 & 36,1 & \\
\hline \multicolumn{8}{|l|}{ Dukungan Keluarga } \\
\hline Kurang & 15 & 20,8 & 0 & 0,0 & 15 & 20,8 & \multirow{3}{*}{0,000} \\
\hline Cukup & 25 & 34,7 & 9 & 12,5 & 34 & 47,2 & \\
\hline Baik & 3 & 4,2 & 20 & 27,8 & 23 & 32,0 & \\
\hline Total & 43 & 59,7 & 29 & 40,3 & 72 & 100 & \\
\hline
\end{tabular}

Sumber : Data Primer, 2016

Faktor sosial ekonomi keluarga berdasarkan variabel umur menunjukkan bahwa berdasarkan uji chi-square diperoleh nilai $\mathrm{p}=0,256$. Oleh karena $\mathrm{p}>0,05$ maka variabel umur ibu secara statistik tidak berhubungan dengan kejadian kurang energi kronis. Menurut peneliti, hal ini disebabkan karena antara umur ibu hamil beresiko dengan umur ibu hamil tidak beresiko mempunyai proporsi yang sama 
untuk mengalami KEK. Keadaan ini menunjukkan bahwa semua wanita hamil berapapun umurnya berisiko untuk mengalami masalah dalam kehamilan bila mengabaikan kebutuhan diri seperti olahraga, makan makanan bergizi sesuai jenis dan jumlah yang tepat, serta melakukan perawatan kehamilan yang berkualitas. Keadaan ini berbeda dengan hasil penelitian yang dilakukan oleh Efrinita (2010), dimana menurutnya ibu yang memiliki umur kurang dari 20 tahun masih berada dalam proses tumbuh kembang sehingga akan terjadi kompetisi makanan antara janin dan ibunya sendiri. Sedangkan pada ibu dengan umur lebih dari 35 tahun kondisi badan dan kesehatan pada ibu sudah mulai menurun sehingga dapat mempengaruhi janin intrauterine dan dapat menyebabkan kelahiran yang beresiko untuk mengalami BBLR (Haryati, 2012).

Berdasarkan uji chi-square terhadap variabel pendidikan menunjukkan nilai $p=0,001$. Oleh karena $p<0,05$ maka variabel tingkat pendidikan ibu secara statistik berhubungan dengan kejadian KEK pada ibu hamil. Responden yang mengalami KEK baik yang berpendidikan rendah maupun yang berpendidikan sedang sebagian besar dari mereka hanyalah ibu rumah tangga yang kesehariannya hanya di rumah sehingga informasi mereka peroleh hanya pada saat posyandu atau pada saat berkunjung ke Puskemas untuk melakukan pemeriksaan kehamilan selebihnya tidak, hal inilah yang menyebabkan pengetahuan atau informasi gizi mereka menjadi terbatas. Penelitian ini sejalan dengan pendapat Berg (1987), dimana menurutnya latar belakang pendidikan seseorang dapat mempengaruhi kualitas dan kuantitas konsumsi makanan, karena dengan tingkat pendidikan yang tinggi diharapkan pengetahuan atau informasi tentang gizi yang dimiliki menjadi lebih baik, sebaliknya masalah gizi timbul karena ketidaktahuan atau kurangnya informasi tentang gizi yang memadai.

Berdasarkan uji chi-square terhadap variabel pekerjaan menunjukkan bahwa nilai $p=0,000$. Oleh karena $p<0,05$ maka variabel pekerjaan secara statistik berhubungan dengan kejadian KEK pada ibu hamil. Berdasarkan hasil penelitian sebagian besar responden yang memiliki suami dengan pekerjaan tidak tetap menerima upah yang tidak menentu setiap bulannya. Keadaan ini yang membuat responden kesulitan dalam memenuhi kebutuhan rumah tangga secara baik terutama dalam menyiapkan makanan sesuai dengan kuantitas dan kualitas yang baik. Penelitian yang dilakukan oleh Mahirawati (2014) menunjukkan hubungan bermakna antara pekerjaan suami dan pendapatan per bulan dengan kejadian KEK pada ibu hamil, dimana 29,9\% ibu hamil KEK lebih banyak terjadi pada ibu yang mempunyai suami dengan pendapatan kurang dari Rp.1.120.000,- per bulan.

Berdasarkan uji chi-square terhadap variabel pendapatan menunjukkan bahwa nilai $p=0,000$. Oleh karena $p<0,05$ maka variabel pendapatan secara statistik berhubungan dengan kejadian KEK pada ibu hamil. Menurut peneliti, karena terbatasnya pendapatan yang diperoleh keluarga menyebabkan kebutuhan untuk makan minum tidak sepenuhnya diprioritaskan karena masih banyaknya kebutuhan lain yang harus dipenuhi, misalnya kebutuhan sekolah maupun kebutuhan rumah tangga seperti listrik, air, dan sebagainya. Responden dalam penelitian ini sebagian besar tidak bekerja atau hanya berprofesi sebagai ibu rumah tangga sehingga pendapatan keluarga sepenuhnya hanya berasal dari pendapatan suami. Keadaan ini sangat berbahaya untuk kesehatan keluarga dan 
akhirnya dapat berakibat buruk terhadap keadaan gizi ibu hamil dan apabila berlangsung dalam waktu yang lama maka berpeluang besar menyebabkan terjadinya ibu mengalami KEK.

Faktor sosial ekonomi keluarga berdasarkan variabel jumlah anggota keluarga berdasarkan uji chi-square menunjukkan nilai $p=0,813$. Oleh karena $p>0,05$ maka variabel jumlah anggota keluarga secara statistik tidak berhubungan dengan kejadian KEK pada ibu hamil. Penelitian ini sesuai dengan Suhardjo (1987) bahwa jumlah anggota keluarga yang besar jika tidak diimbangi dengan peningkatan pendapatan akan memperburuk gizi keluarga. Namun, meskipun jumlah anggota keluarga besar tetapi apabila ibu tetap memperhatikan pola makan dengan baik dan seimbang, ibu hamil tidak akan mengalami KEK. Sebaliknya sekalipun keluarga dengan jumlah anggota keluarga yang kecil namun memiliki pendapatan yang rendah akan menyebabkan keluarga kurang leluasa memilih makanan yang beragam dan bergizi sesuai dengan kebutuhan (Fitrianingsih, 2014).

Faktor sosial ekonomi keluarga berdasarkan variabel dukungan keluarga menunjukkan bahwa responden yang kurang mendapat dukungan keluarga sebesar 20,8\% mengalami KEK sedangkan responden yang mendapat dukungan keluarga yang baik yakni sebesar 27,8\% tidak mengalami KEK. Berdasarkan uji chi-square menunjukkan nilai $p=0,000$. Oleh karena $p<0,05$ maka variabel dukungan keluarga secara statistik berhubungan dengan kejadian KEK pada ibu hamil. Berdasarkan hasil wawancara terhadap ibu hamil, diketahui bahwa sebagian besar ibu hamil pergi ke Puskesmas untuk memeriksakan kehamilan tanpa didampingi oleh suami maupun salah satu keluarga. Menurut mereka hal ini sudah sering dilakukan mengingat baik suami maupun keluarga juga memiliki kesibukan sendiri sehingga tidak sempat untuk mengantar. Disamping itu beberapa diantara mereka menyatakan tidak ada yang berbeda antara sebelum dan setelah hamil. Setelah diteliti ternyata dukungan keluarga sangat diharapkan oleh seorang ibu hamil dalam menghadapi proses persalinan, dengan dukungan keluarga yang baik akan mengurangi stress pada ibu sehingga proses persalinan lebih cepat dan lancar tanpa adanya komplikasi (Arifin, 2015).

\section{F. Hubungan Pola Konsumsi Pangan dengan Kejadian Kurang Energi Kronis Pada Ibu Hamil}

Tabel 2 .Hubungan Pola Konsumsi Pangan dengan Kejadian Kurang Energi Kronis Pada Ibu Hamil di Kecamatan Oebobo Kota Kupang Tahun 2016

Kejadian Kurang Energi Kronis Pada Ibu Hamil

\begin{tabular}{lccccccc} 
& \multicolumn{7}{c}{ Kejadian Kurang Energi Kronis Pada lbu Hamil } \\
\cline { 2 - 8 } \multicolumn{1}{c}{$\begin{array}{c}\text { Pola Konsumsi } \\
\text { Pangan }\end{array}$} & KEK & $\%$ & $\begin{array}{c}\text { Tidak } \\
\text { KEK }\end{array}$ & $\%$ & Total & $\%$ & P value \\
\hline Jenis Pangan & & & & & & & \\
\hline Kurang & 31 & 43,0 & 0 & 0 & 31 & 43,0 & \\
Cukup & 12 & 16,7 & 16 & 22,2 & 28 & 38,9 & 0,000 \\
Baik & 0 & 0 & 13 & 18,1 & 13 & 18,1 & \\
\hline Jumlah Pangan & & & & & & & 0,000 \\
\hline Kurang & 33 & 45,8 & 0 & 0 & 33 & 45,8 & \\
\end{tabular}




\begin{tabular}{lccccccc} 
Cukup & 10 & 13,9 & 16 & 22,2 & 26 & 36,1 & \\
Baik & 0 & 0 & 13 & 18,1 & 13 & 18,1 & \\
\hline Frekuensi Makan & & & & & & & \\
\hline Tidak Baik & 9 & 12,5 & 0 & 0 & 9 & 12,5 & 0,008 \\
Baik & 34 & 47,2 & 29 & 40,3 & 63 & 87,5 & \\
\hline $\begin{array}{l}\text { Pantangan } \\
\text { Makanan }\end{array}$ & & & & & & & \\
\hline Ada Pantangan & 1 & 1,4 & 2 & 2,8 & 3 & 4,2 & \multirow{2}{*}{0,341} \\
$\begin{array}{l}\text { Tidak Ada } \\
\text { Pantangan }\end{array}$ & 42 & 58,3 & 27 & 37,5 & 69 & 95,8 & \\
\hline Total & 43 & 59,7 & 29 & 40,3 & 72 & 100 & \\
\hline Sumber : Data Primer, 2016 & & & & & &
\end{tabular}

Pola konsumsi telah diketahui sebagai salah satu faktor risiko dari masalah gizi ibu hamil. Pola konsumsi makan ibu hamil dipengaruhi oleh pola konsumsi keluarga dan distribusi makanan yang terdiri dari jumlah, jenis, frekuensi, serta pantangan makan. Pantangan dalam mengonsumsi jenis makanan tertentu dapat dipengaruhi oleh faktor budaya/kepercayaan yang terdapat dalam masyarakat setempat.

Variabel jenis pangan berdasarkan uji chi-square menunjukkan nilai $p=0,000$. Oleh karena $p$ $<0,05$ maka variabel jenis pangan secara statistik berhubungan dengan kejadian KEK pada ibu hamil. Kecenderungan masyarakat dalam mengkonsumsi jenis pangan dalam kategori lengkap sulit ditemukan pada ibu hamil di wilayah kerja kecamatan Oebobo, hal ini disebabkan karena faktor pendapatan yang memaksa mereka untuk mengkonsumsi pangan dengan jenis yang terbatas. Adapun menu lengkap yang ditemukan hanya pada siang hari, sedangkan untuk pagi dan pada malam hari hanyalah menu sisa dari menu makan siang, bahkan sebagian besar dari responden menyebutkan bahwa makanan yang dikonsumsi setiap hari tidak harus memenuhi kriteria menu gizi seimbang, asalkan ada nasi maka yang lainnya hanya dianggap sebagai pelengkap. Keadaan ini terlihat dari jenis pangan yang dikonsumsi dimana jika sudah ada lauk-pauk maka sayuran dihilangkan, ataupun sebaliknya yakni jika sudah ada sayuran maka lauk-pauk pun dihilangkan. Hal ini sangat berbeda dengan pernyataan Pertiwi (2013) dimana menurutnya untuk memperoleh pengaruh yang lebih baik dari pola makan ibu, maka perlu diperhatikan prinsip menu gizi seimbang dimana jumlah lebih banyak, mutu lebih baik, dan susunan menu juga harus seimbang. Adapun menu ibu hamil yang seimbang setara dengan nasi/pengganti 5-6 pring, lauk hewani 4-5 potong, lauk nabati 3-4 potong, sayuran 2-3 mangkuk, buah-buahan 3 potong dan dianjurkan minum 8-12 gelas/hari.

Variabel jumlah pangan berdasarkan uji chi-square menunjukkan nilai $p=0,000$. Oleh karena $p<0,05$ maka variabel jumlah pangan secara statistik berhubungan dengan kejadian KEK pada ibu hamil. Hal ini berarti bahwa sebagian besar ibu hamil yang mengalami KEK mengkonsumsi energi kurang dari $2.300 \mathrm{kkal} /$ orang/hari dan protein kurang dari $67 \mathrm{gr} /$ orang/hari. Padahal jumlah atau porsi makan yang dikonsumsi seseorang mempengaruhi zat gizi yang masuk ke dalam tubuh. Keadaan ini 
menyebabkan wanita hamil memerlukan tambahan energi untuk pertumbuhan janin, plasenta, dan jaringan tubuh ibu lainnya.

Variabel frekuensi makan berdasarkan uji chi-square menunjukkan nilai $p=0,008$. Oleh karena $p<0,05$ maka variabel frekuensi makan secara statistik berhubungan dengan kejadian KEK pada ibu hamil. Frekuensi makan merupakan seberapa sering seseorang mengkonsumsi makanan yang merupakan kontributor penting terhadap asupan energi dan zat - zat gizi. misalnya frekuensi mengkonsumsi daging, ayam, ikan, kacang - kacangan, buah dan sayuran. Secara alamiah makanan diolah dalam tubuh melalui alat-alat pencernaan mulai dari mulut sampai usus halus. Lama makanan dalam lambung tergantung sifat dan jenis makanan. Jika rata-rata, umumnya lambung kosong antara 3-4 jam, maka jadwal makan ini pun menyesuaikan dengan kosongnya lambung (Oktoviani, 2011). Frekuensi makan berkaitan dengan pemenuhan kebutuhan zat gizi yang dibutuhkan oleh tubuh. Pada ibu hamil, pola makan yang dianjurkan bagi ibu hamil yaitu porsi makan yang kecil tapi sering minimal lima kali sehari (Oktriyani, 2014). Berdasarkan penelitian yang dilakukan terhadap responden sebanyak $12,5 \%$ ibu hamil mempunyai kebiasaan makan yang tidak teratur dimana dalam sehari ibu hanya mengkonsumsi makanan hanya sebanyak 2 kali sehari yakni pagi dan siang, atau siang dan sore itupun dengan porsi yang kecil. Keadaan ini terus berlangsung selama kehamilan, dimana menurut mereka selama masa kehamilan nafsu makan mereka menurun, makan makanan secara berlebihan hanya membuat rasa mual dan muntah yang lama kelamaan akan membuat tubuh terasa lemah dan kepala terasa pusing. Sebagian ibu berpendapat bahwa jika merasa lapar maka mereka hanya menggantinya dengan makan yang manis - manis seperti permen atau buah semangka yang mengandung banyak air sehingga sudah membuat kenyang walaupun hanya bersifat sementara sambil menunggu waktu makan berikutnya. Seharusnya pada trimester II dan III kebutuhan akan zat tenaga lebih banyak dibandingkan dengan kebutuhan saat trimester I, demikian juga dengan zat pembangun dan zat pengatur seperti lauk-pauk, sayuran dan buah-buahan, hal ini dikarenkan pada masa ini janin mengalami pertumbuhan dan perkembangan yang sangat pesat dan juga nantinya sebagai bentuk persiapan ibu dalam menghadapi proses persalinan. Jika asupan makanan pada ibu hamil menunjukkan jumlah makanan yang kurang maka secara langsung akan menyebabkan terjadinya defisiensi baik energi maupun vitamin dan mineral, dan merupakan penyebab terjadinya malnutrisi pada ibu hamil (Soetjiningsih, 2012).

Variabel pantangan makanan berdasarkan uji chi-square menunjukkan nilai $p=0,341$. Oleh karena $p>0,05$ maka variabel pantangan makanan secara statistik tidak berhubungan dengan kejadian KEK pada ibu hamil. Berdasarkan hasil wawancara dengan responden, satu orang responden mengatakan bahwa tidak mengkonsumsi jenis makanan hasil laut seperti ikan, udang, cumi-cumi maupun kepiting, hal ini bukan saja baru dilakukan setelah yang bersangkutan dalam keadaan hamil melainkan sudah diterapkan dari zaman nenek moyang, bahkan sampai suami maupun anak-anaknya juga mengikuti kebiasaan tersebut hingga sekarang. Berbeda dengan responden tersebut, dua responden lainnya menyatakan bahwa mereka tidak mengkonsumsi telur dengan alasan eksim atau 
alergi pada kulit. Menurut responden jika mereka tidak dapat mengkonsumsi salah satu jenis makanan tersebut mereka dapat menggantinya dengan jenis makanan lain yang tidak kalah nilai gizinya, disamping itu pantangan makanan ini tidak saja dialami oleh ibu hamil yang mengalami KEK, bahkan ibu yang tidak KEK pun mengalami hal yang serupa. Penelitian ini sesuai dengan penelitian yang dilakukan oleh Oktriyani (2014) dimana tidak ada hubungan antara pantangan makanan dengan kejadian KEK pada ibu hamil dimaan $\mathrm{p}>0,05(\mathrm{p}=0,44)$.

\section{G. Hubungan Riwayat Penyakit Infeksi dengan Kejadian Kurang Energi Kronis Pada Ibu Hamil}

Tabel 3. Hubungan Riwayat Penyakit Infeksi dengan Kejadian Kurang Energi Kronis Pada Ibu Hamil di Kecamatan Oebobo Kota Kupang Tahun 2016

$$
\text { Kejadian Kurang Energi Kronis Pada Ibu Hamil }
$$

\begin{tabular}{lccccccc}
\hline & \multicolumn{7}{c}{ Kejadian Kurang Energi Kronis Pada Ibu Hamil } \\
\cline { 2 - 8 } \multicolumn{1}{c}{$\begin{array}{c}\text { Riwayat Penyakit } \\
\text { Infeksi }\end{array}$} & KEK & $\%$ & $\begin{array}{c}\text { Tidak } \\
\text { KEK }\end{array}$ & $\%$ & Total & $\%$ & $p$ value \\
\hline Ada & 3 & 4,2 & 1 & 1,4 & 4 & 5,6 & 0,521 \\
Tidak Ada & 40 & 55,5 & 28 & 38,9 & 68 & 94,4 & \\
\hline Total & 43 & 59,7 & 29 & 40,3 & 72 & 100 & \\
\hline Sumber : Data Primer, 2016 & & & & & &
\end{tabular}

Variabel riwayat penyakit infeksi berdasarkan uji chi-square menunjukkan nilai $p=0,521$. Oleh karena $p>0,05$ maka variabel riwayat penyakit infeksi secara statistik tidak berhubungan dengan kejadian KEK pada ibu hamil. Hasil penelitian ini menunjukkan dari 72 responden, 68 (44,4\%) responden tidak memiliki riwayat penyakit infeksi, namun 3 responden mempunyai riwayat penyakit tipes yang sudah lama pernah diderita ibu bahkan sebelum kehamilan, sedangkan 1 responden lainnya pernah menderita diare pada pada trimester I. Meskipun penyakit infeksi pernah menyerang tubuh, namun menurut responden sakit yang dialaminya tidak sampai berlarut-larut atau berkepanjangan karena segera mendapat pertolongan medis dan tidak pernah kambuh lagi hingga saat ini. Hal ini berarti bahwa penyakit infeksi bukan merupakan satu-satunya faktor penyebab terjadinya KEK pada ibu hamil. Hasil penelitian ini sejalan dengan penelitian yang dilakukan oleh Surasih (2005), yang menyatakan tidak ada hubungan antara riwayat penyakit infeksi dengan kejadian KEK pada ibu hamil di Kabupaten Banjarnegara dengan nilai $\mathrm{p}>0,05$, dimana menurutnya ibu hamil yang terkena penyakit infeksi mempunyai risiko relatif sama untuk terkena KEK dibandingkan dengan ibu hamil yang tidak terkena penyakit infeksi.

\section{H. Hubungan Secara Simultan antara Faktor Sosial Ekonomi Keluarga (Pekerjaan) dengan Kejadian Kurang Energi Kronis Pada Ibu Hamil di Kecamatan Oebobo Kota Kupang}

Hasil analisis bivariat menggunakan uji chi-square menunjukkan bahwa variabel independen yang dapat masuk kedalam analisis simultan multivariat adalah variabel dengan nilai signifikannya 
$<0,05$. Variabel independen dengan nilai $p$ valuenya $<0,05$ adalah sub variabel pekerjaan ( $p$ valuae $=$ $0,026<0,05)$. Berdasarkan hasil akhir analisis multivariat menggunakan uji statistik Regresi logistik berganda dapat dilihat pada tabel 4. dibawah ini.

Tabel 4. Variables in The Equation (Hasil Akhir Regresi Logistik)

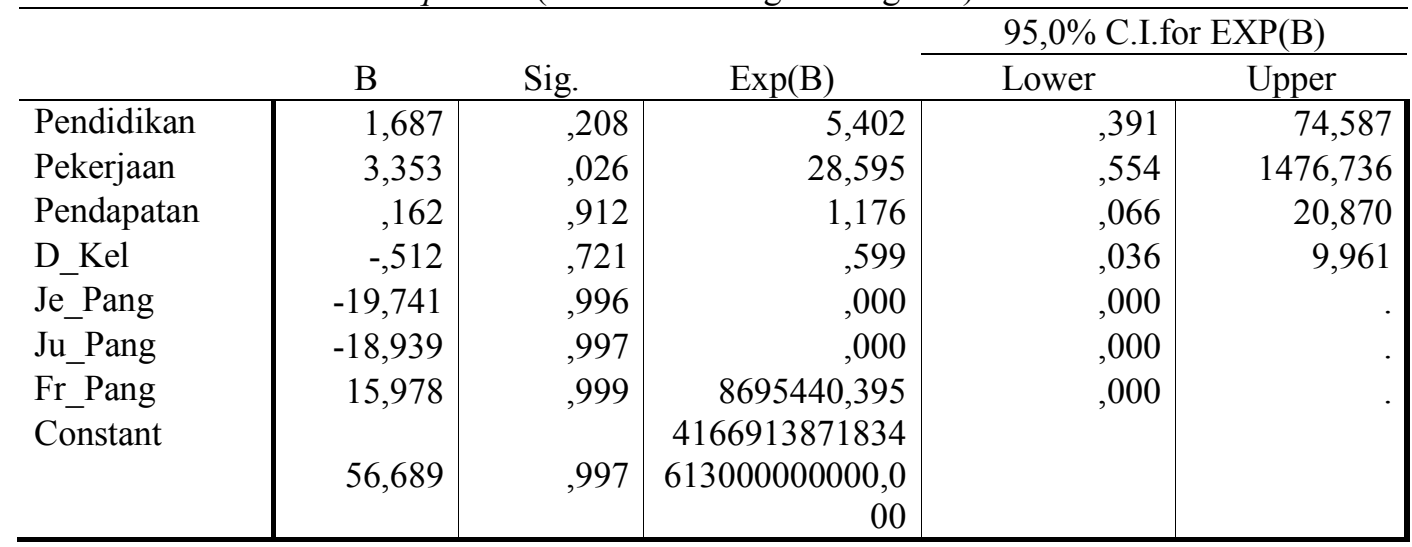

Berdasarkan tabel 4. diatas, dapat diketahui 3 hal berikut :

1. Variabel independen yang berhubungan signifikan secara simultan dengan variabel dependen kejadian KEK pada ibu hamil adalah variabel yang memiliki nilai $\mathrm{p}<0,05$ yaitu pekerjaan $(\mathrm{p}=$ $0,026)$.

2. Variabel independen yang menjadi faktor dominan secara simultan berhubungan dengan kejadian KEK pada ibu hamil adalah pekerjaan $(\mathrm{p}=0,026)$ dengan peluang terjadinya KEK sebesar 28 kali.

3. Model regresi logistik kejadian KEK pada ibu hamil

Berdasarkan tabel 4.14 dalam Variables in The Equation, dapat diketahui bahwa konstanta $(\alpha)$ adalah sebesar 56,689. Jika $X_{1}$ adalah nilai variabel pekerjaan maka nilai koefisien dari variabel pekerjaan $\left(\beta_{1}\right)$ adalah sebesar 3,353 . Sehingga jika dimasukkan dalam rumus umum regresi logistik adalah :

$$
\begin{aligned}
& \operatorname{In}\left(\frac{\mathrm{p}}{1-\mathrm{p}}\right)=\mathrm{y} \\
& \operatorname{In}\left(\frac{\mathrm{p}}{1-\mathrm{p}}\right)=\beta_{1} \mathrm{X}_{1}+\beta_{2} \mathrm{X}_{2}+\ldots \ldots \ldots \ldots \ldots \ldots \ldots \ldots \ldots+\beta_{\mathrm{i}} \mathrm{X}_{\mathrm{i}}
\end{aligned}
$$

Maka model atau rumus umum probabilitas terjadinya KEK pada ibu hamil adalah :

$$
\operatorname{In}\left(\frac{p}{1-p}\right)=56,689+3,353\left(X_{1}\right)
$$




$$
\mathrm{f}(\mathrm{y})=\frac{1}{1+\mathrm{e}^{-\{56,689+3,353 \text { (Pekerjaan) }\}}}
$$

Intepretasi model persamaan regresi logistik diatas adalah jika suami selaku kepala keluarga memiliki pekerjaan bersifat tidak tetap maka kecenderungan terjadinya KEK pada ibu hamil sebanyak 3,353 kali. Penurunan kejadian KEK akan terjadi jika suami sebagai kepala keluarga memiliki pekerjaan tetap.

\section{PENUTUP}

Berdasarkan hasil yang diperoleh dalam penelitian ini maka dapat disimpulkan beberapa hal, sebagai berikut:

1. Presentase responden berdasarkan agama yang dianut sebagian besar responden di Kecamatan Oebobo menganut agama Kristen Protestan sebesar 61,1\% dengan Suku terbanyak yakni suku Timor sebanyak 50,0\%, dimana $81,9 \%$ responden telah berstatus menikah dengan Paritas Nulipara terbanyak yakni sebesar $45,8 \%$. Responden kebanyakan memiliki umur kehamilan pada trimester II yakni sebanyak $62,5 \%$.

2. Ada hubungan bermakna antara faktor sosial ekonomi keluarga dan pola konsumsi pangan dengan kejadian KEK pada ibu hamil di Kecamatan Oebobo Kota Kupang dengan nilai $p$ value < 0,05 .

3. Secara simultan variabel pekerjaan mempunyai hubungan yang bermakna dengan kejadian KEK pada ibu hamil di Kecamatan Oebobo Kota Kupang.

\section{DAFTAR PUSTAKA}

1. Arifin. 2015. Peran Keluarga Terhadap Proses Penyembuhan Pasien Perilaku Kekerasan di Panti Rehabilitasi Mental Wisma Budi Makarti Boyolali. Surakarta : Stikes Kusuma Husada Surakarta

2. Berg. 1987. Peranan Gizi dalam Pembangunan. Jakarta : Rajawali

3. Depkes RI. 2002. Pedoman Umum Gizi Seimbang. Direktorat Jenderal Bina Kesehatan Masyarakat. Jakarta

4. Depkes RI. 2009. Sistem Kesehatan Nasional. Jakarta

5. Efrinita.2010. Hubungan Antara Asupan Protein Dengan Kekurangan Energi Kronik (KEK) Pada Ibu Hamil Di Kecamatan Jebres Surakarta. Skripsi. Universitas Sebelas Maret Surakar

6. Fitrianingsih. 2014. Hubungan Pola Makan dan Status Sosial Ekonomi dengan Kejadian Kurang Energi Kronik Pada Ibu Hamil di Puskesmas Tompouolu Kabupaten Gowa Tahun 2014. Makasar : Universitas Allaudin

7. Haryati, N. 2012. Analisis Faktor-Faktor yang Memengaruhi Berat Badan Bayi Saat Lahir di Kota Surakarta Menggunakan Metode Pohon Regresi. Prosiding Seminar Nasional Matematika Tahun 2012.

8. Mahirawati, Vita Kartika. 2014. Faktor-Faktor yang Berhubungan dengan Kurang Energi Kronis Pada Ibu Hamil di Kecamatan Kamoningdan Tambelangan Kabupaten Sampang. Jawa Timur : Jurnal Penelitian

9. Oktaviani W. 2011. Hubungan Pola Makan dengan Gastritis pada Mahasiswa S1 Keperawatan Program A FIKES UPN Veteran Jakarta 
10. Oktriyani. 2014. Hubungan Pola Makan dan Pantangan Makan dengan Kekurangan Energi Kronis Pada Ibu Hamil di Kabupaten Bantul Daerah Istimewa Yogyakarta Tahun 2014. Yogyakarta : Universitas Gadjah Mada

11. Pertiwi, Aldila. 2013. Hubungan Antara Pola Makan Dengan Kejadian Anemia Pada Ibu Hamil Di Wilayah Kerja Puskesmas Kerjo Kabupaten Karanganyar. Skrpsi : Universitas Muhammadiyah Surakarta

12. Riset Kesehatan Dasar. 2013. Badan Penelitian dan Pengembangan Kesehatan Kementerian RI tahun 2013

13. Soetjiningsih. 2012. Perkembangan Anak dan Permasalahannya dalam Buku Ajar I Ilmu Perkembangan Anak Dan Remaja. Jakarta :Sagungseto

14. Suhardjo, 1989. Sosio Budaya Gizi. IPB. Bogor.

15. Surasih, H. 2006. Faktor-faktor yang Berhubungan dengan Keadaan Kekurangan Energi Kronik (KEK) Pada Ibu Hamil di Kabupaten Banjar Negara. Skripsi : Universitas Negeri Semarang

16. Susilo, J. 2000. Hubungan Antara Intake Zat Besi, Kalsium, Tanin, Fitat, dan Oksalat Dengan Kadar Hb Ibu Hamil di Kabupaten Bantul. Tesis. Yogyakarta : Universitas Gajah Mada 